\title{
African leafy vegetables in South Africa
}

\author{
WS Jansen van Rensburg ${ }^{1 *}$, W van Averbeke², R Slabbert ${ }^{2}$, M Faber $^{3}$, P van Jaarsveld $^{3}$, \\ I van Heerden ${ }^{4}$, F Wenhold ${ }^{5}$ and A Oelofse ${ }^{6}$ \\ ${ }^{1}$ Agricultural Research Council - Vegetable and Ornamental Plant Institute, Private Bag X293, Pretoria 0001, South Africa \\ ${ }^{2}$ Centre for Organic \& Smallholder Agriculture, Department of Crop Sciences, Tshwane University of Technology, \\ Private Bag X680, Pretoria 0001, South Africa \\ ${ }^{3}$ Medical Research Council, Nutrition Intervention Research Unit, Private Bag X19, Parow 7925, South Africa \\ ${ }^{4}$ Agricultural Research Council - ANAPI, Meat Industry Centre, Private Bag X2, Irene 0062, South Africa \\ ${ }^{5}$ University of Pretoria - Division of Human Nutrition, Faculty of Health Sciences, PO Box 667, Pretoria 0001, South Africa \\ ${ }^{6}$ University of Pretoria - Centre for Nutrition, Faculty of Natural and Agricultural Sciences, Pretoria 0002, South Africa
}

\begin{abstract}
In this article the term 'African leafy vegetables' was adopted to refer to the collective of plant species which are used as leafy vegetables and which are referred to as morogo or imifino by African people in South Africa. Function is central in this indigenous concept, which is subject to spatial and temporal variability in terms of plant species that are included as a result of diversity in ecology, culinary repertoire and change over time. As a result, the concept embraces indigenous, indigenised and recently introduced leafy vegetable species but this article is concerned mainly with the indigenous and indigenised species. In South Africa, the collection of these two types of leafy vegetables from the wild, or from cultivated fields where some of them grow as weeds, has a long history that has been intimately linked to women and their traditional livelihood tasks. Among poor people in remote rural areas the use of these types of leafy vegetables is still common but nationwide there is evidence of decline, particularly in urban areas. Cultivation of indigenous or indigenised leafy vegetables is restricted to a narrow group of primarily indigenised species in South Africa. Seven groups of indigenous or indigenised African leafy vegetables that are important in South Africa were given special attention and their local nomenclature, ecology, use and cultivation are discussed.
\end{abstract}

Keywords: African leafy vegetables, morogo, imifino, history, ecology, gender, collection, cultivation, use, processing, storage

\section{Introduction}

In South Africa, the use of leafy vegetables is as old as the history of modern man. Khoisanoid people who have lived in Southern Africa for at least the past 120000 years, relied heavily on the gathering of plants from the wild for their survival (Fox and Norwood Young, 1982; Parsons, 1993). The Bantu-speaking tribes which started to settle in South Africa about 2000 years ago also collected leafy vegetables from the wild (Bundy, 1988). In their food system hunting and the collection of edible plants were particularly important during times of emergency, when crops had failed or livestock herds had been decimated (Peires, 1981). Collecting and cultivating green leafy vegetables continues to be widespread among African people in South Africa (Bhat and Rubuluza, 2002; Jansen van Rensburg et al., 2004, Husselman and Sizane, 2006; Modi et al., 2006) even though western influences have considerably modified their food consumption patterns.

The objectives of this article are to provide an overview of the use and status of leafy vegetables in contemporary African communities of South Africa and to present information on the local nomenclature, botanical description, ecology, utilisation and cultivation of seven groups of species that are commonly used by these communities.

\footnotetext{
* To whom all correspondence should be addressed.

III +2712 841 9611; fax: +2712 808 0348; e-mail: wjvrensburg@arc.agric.za
}

\section{Use and status of leafy vegetables in contemporary South African society}

Leafy vegetables are plant species of which the leafy parts, which may include young, succulent stems, flowers and very young fruit, are used as a vegetable. In South Africa, Wehmeyer and Rose (1983) identified more than 100 different species of plants that were being used as leafy vegetables. African people refer to these plant species collectively, using the term morogo (Sesotho, isiPedi) or imifino (isiZulu, isiXhosa), which freely translated means leafy vegetables. This dynamic concept is particularly useful when approaching leafy vegetables from the perspective of contemporary indigenous knowledge and practice. What exactly constitutes morogo or imifino is subject to spatial and temporal variability. The plant species that are included depend on the local ecology and culinary traditions (Levy et al., 1936; Van Wyk and Gericke, 2000; Vorster et al., 2002). Focusing on the use rather than the origin of plant species, the concept is dynamic because it is subject to the addition of new species to the collective, such as the fairly recently introduced, exotic Swiss chard (Beta vulgaris). In this article, the term 'African leafy vegetables' was adopted to reflect the meaning of morogo or imifino and was defined as the collective of leafy vegetable species that form part of the culinary repertoire of particular contemporary African communities. True to the meaning of morogo or imifino, the term African leafy vegetables embraces indigenous, indigenised and recently introduced plant species but the focus of this article is on indigenous and indigenised species. Indigenous leafy vegetables may be defined as plant species which are either genuinely native to a particular region, or 
which were introduced to that region for long enough to have evolved through natural processes or farmer selection. In line with the concept of indigenisation defined by Phillips-Howard (1999), a leafy vegetable species is called indigenised in a particular region when it was externally derived but has since been incorporated in the local food culture.

African people obtain leafy vegetables in different ways. They may be harvested from the wild or from fallow and cultivated fields, or they may be cultivated. The plant species that are used as leafy vegetables are also variable in terms of their origin. Species growing in the wild or as weeds may be indigenous or introduced from elsewhere. Similarly, species that are cultivated may be indigenous crops or exotic in origin and their cultivation may be traditional practice or recent innovation.

For most species the young growth points and tender leaves are the plant parts that are used in the preparation of vegetable dishes. Petioles and in some cases young tender stems are also included, but old, hard stems are discarded (Vorster et al., 2002). The leaves and other selected plant parts are prepared as potherbs or as relishes, primarily to accompany maize porridge and sorghum. The leafy vegetable dishes may be prepared from a single species or from a combination of different species. Other ingredients, such as tomatoes, onions, peanut flour and spices may be added to enhance their taste. Cooking methods vary from thorough boiling, which may include the replacement of the first cooking water with fresh water in the case of bitter-tasting species, such as Solanum retroflexum (Van Averbeke and Juma, 2006a), to steaming involving the use of very small quantities of water and short cooking times, as in the case of pumpkin leaves and flowers. According to Vorster et al. (2005), the recipes used to prepare the different leafy vegetables tend to be fairly homogeneous within particular cultural groups limiting culinary diversity.

Historically, the collecting of leafy vegetables and the knowledge associated with this practice was a female domain among both the Khoisan (Fox and Norwood Young, 1982; Parsons, 1993) and the Bantu-speaking tribes (Jansen van Rensburg et al., 2004). In contemporary South Africa this practice continues to be associated with women. However, the available evidence indicates that once a particular plant species becomes domesticated and is grown as a crop, men readily become involved, especially when its production is commercialised (Van Averbeke and Juma, 2006a). Leafy vegetables also tend to be regarded as a female food, but gender distinctions in terms of their consumption are much less universal than in terms of their collection (Whitbread, 1986; Hart and Vorster, 2006).

Many of the leafy vegetable species, especially those that grow as weeds or in the wild, are seasonal and highly perishable. To extend the period during which they are available, different ways of preserving these vegetables have been developed. The two main methods are the sun-drying of fresh leaves and the sun-drying of blanched or cooked leaves. Both these methods transform the leafy vegetables into dry products that have long shelf lives (Vorster et al., 2005). Invariably the dry vegetables are re-hydrated by cooking in water. Electrification of the rural areas has introduced new preservation technology, including the blanching and freezing of leaves (Tshikalange and Van Averbeke, 2006a)

The role of leafy vegetables in the food consumption patterns of South African households is highly variable and depends on factors such as poverty status, degree of urbanisation, distance to fresh produce markets and time of year (Vorster et al., 2002). Quantitatively, the consumption of leafy vegetables collected from the wild or as weeds tends to be inversely proportional to household income (Vorster et al., 2002). Poor households tend to use these types of leafy vegetables more than their wealthier counterparts, because they lack the financial means to purchase vegetables and the wherewithal to produce their own (Vorster et al., 2002). The use of wild food forms part of the safety net that rural people use to cope with poverty, disaster and livelihood stress (Rose and Guillarmod, 1974; Rubaihayo, 1997; Shackleton et al., 2000). During periods of drought, or when the breadwinner in the household becomes unemployed, affected rural households intensify their collection and consumption of wild food (Shackleton, et al., 1999; Dovie, et al., 2002; Shackleton, 2003). Social disturbances can also lead to increased use of wild food. For example, during the pre-1994 political struggle in the Transkei region of the Eastern Cape, people fleeing their houses to escape violence relied heavily on food collected from veld and forest for survival (Jansen van Rensburg and Vorster, 2005). In poor rural communities consumption of wild food is particularly important for women and children (Shackleton et al. 2002a, Vorster and Jansen van Rensburg, 2005). Use of wild food is also enhanced by remoteness because households in remote rural areas have limited access to fresh produce markets (Jansen van Rensburg and Vorster, 2005; Hart and Vorster, 2006). Urban households use leafy vegetable collected from the wild less than rural households, because they lack access to sites where these vegetables grow naturally.

The monetary value of the products rural people harvest from the wild, including leafy vegetables, has been determined by means of case studies in the Limpopo, KwaZulu-Natal and Eastern Cape Provinces of South Africa (Shackleton et al., 1999; Twine et al., 2001; Magasela et al., 2001; Shackleton et al., 2002a; Shackleton et al., 2002b; Shackleton et al., 2007). Across the case studies, the most widely used leafy vegetable species harvested from the wild or as weeds were Amaranthus hybridus, Biddens pilosa, B. biternata, Cleome gynandra, Corchorus tridens, Chenopodium album and Tribulus terrestris. Use of these leafy vegetables was largely restricted to home consumption. Generally, harvesting leafy vegetables from the wild was most important in Limpopo Province and least in the Eastern Cape.

On the African continent as a whole, production, trade and consumption of indigenous and indigenised African leafy vegetables are expanding (Schippers, 2000; 2002; 2006). In contemporary South Africa, different, often opposing trends are discernable. For a long time South African researchers and policy makers have ignored these types of leafy vegetables, but during the past two decades this has changed. Indigenous and indigenised African leafy vegetables have increasingly received attention from South African researchers and at the policy level the value of these plants has been recognised (Department of Agriculture, 2004). The growing interest in these vegetables in both research and policy circles contrasts sharply with the negative image these plants have come to carry among important potential groups of consumers in South African society, particularly the youth and the urbanised, who tend to associate their consumption with poverty and the past (Vorster et al., 2002; Hart and Vorster, 2006). Even in selected rural areas of the country a decline in the consumption of these leafy vegetables, particularly those that are harvested from the wild or as weeds, in favour of exotic vegetables has been observed. This was evident from the recent case study conducted by Jansen van Rensburg and Vorster (2005) in three parts of the former Transkei in the Eastern Cape Province, which showed that the use of these types of leafy vegetables has been declining at all three sites during much of the twentieth century, particularly at Qunu, where access to exotic vegetables was the easiest, because of its proximity to Mmtata, 
the largest urban centre in the Transkei region. At Dimfi, which was the most remote of the three rural study sites, the decline in the use was the least. By contrast, during the past 50 years in the Vhembe District of the Limpopo Province, the status of nightshade (Solanum retroflexum Dun.) has been elevated from that of a plant that was exclusively collected from the wild to that of a fresh produce commodity that is being cultivated extensively under irrigation by local smallholders and retailed by both petty traders and large supermarket outlets (Van Averbeke and Juma, 2006a).

In South Africa, the marketing of leafy vegetables harvested from the wild or as weeds is limited and mostly restricted to dried products (Vorster et al., 2002; Vorster and Jansen van Rensburg, 2005; Hart and Vorster, 2006). Whitbread (1986) reported on the marketing of different species of amaranth which were collected as weeds from fields and gardens in the KwaZulu-Natal Midlands. Marketing of the amaranths was mainly by petty traders but the leaves were also available at the municipal fresh produce market of Pietermaritzburg and they were offered for sale to the public by selected greengrocers in that city.

\section{Important African leafy vegetable species in South Africa}

In South Africa, many leafy vegetables are obtained by collecting and not by means of cultivation. Limited broadcasting of the seed of selected species in fields does occur (Vorster et al., 2002; Hart and Vorster, 2006) and a limited number of species are being cultivated (Kirsten, 1977; Fox and Norwood Young, 1982; Hart and Vorster, 2006). Among the most popular leafy vegetables that are obtained by collection rather than cultivation, several species, such as amaranth and spider flower, are pioneer plants which emerge naturally when soils are disturbed. They are regarded as weeds in commercial farming systems (Grabandt, 1985) but not in African smallholder cropping systems. Women who do most of the weeding in smallholder cropping systems often distinguish between undesirable weed species, which are hoed or pulled out, and species that belong to the local collective of leafy vegetable species, which are harvested or left undisturbed for subsequent use (Hart and Vorster, 2006). Most of the species that are consumed as leafy vegetables grow in summer. Exceptions are the local Brassica species and Chenopodium album which grow during winter (Levy et al., 1936; Whitbread, 1986).

The popularity of specific species is function of many factors, including availability, ease of preparation, taste, consistency and appearance. The ubiquitous availability of amaranth species explains why these plants are used as a leafy vegetable in most parts of South Africa. The soft, fast-cooking leaves of pumpkin and nightshade species are preferred to the fibery leaves of cowpeas and old amaranth plants which require long cooking times (Fox and Norwood Young, 1982). Taste, another very important factor, is subject to regional and gender diversity. In the north of South Africa the bitter taste of nightshade and cleome are highly appreciated, particularly by males, whereas in the south the sweet taste of amaranth leaves is preferred (Vorster et al., 2002). Similarly, many people in the north enjoy the mucilaginous texture of Corchorus and okra, whereas people in the south dislike sliminess (Vorster et al., 2002).

When recent additions, such as Swiss chard, are ignored, the available evidence obtained from different parts of the country indicates that seven groups of leafy vegetable species are of particular importance in contemporary South Africa. These are amaranth (Amaranthus spp), spider flower (Cleome gynandra), rape or Chinese cabbage (Brassica rapa subsp. chinensis), nightshade (Solanum retroflexum and selected other species belonging to the $S$. nigrum complex), Jew's mallow (Corchorus olitorius and C. tridens), cowpeas (Vigna inguiculata) and pumpkins (Cucurbita pepo, C. maxima and C. moschata), melons (Citrullus lanatus and Cucumis melo) and selected other indigenous cucurbits, such as balsam pear (Momordica balsamina).

\section{Amaranth (Amaranthus spp.)}

Amaranth is known as misbredie, hanekam, varkbossie in Afrikaans, pigweed, cockscomb and hell's curse in English, unomdlomboyi, imbuya, umifino umtyuthu in isiXhosa, imbuya, isheke, indwabaza in isiZulu, thepe, theepe in IsiPedi, Sesotho and Setswana, umbuya, isheke in siSwati, vowa, theebe in Tshivenda, theyke, cheke in Xitsonga, mohwa in Shona and imbuya, tyutu in Pondo (Fox and Norwood Young, 1982; Bromilow, 1995; Van Wyk and Gericke, 2000, Vorster et al., 2002).

Amaranth belongs to the Amaranthaceae family and is an extremely variable, erect to spreading herb (Fig. 1). The height of mature plants varies between $0.3 \mathrm{~m}$ and $2 \mathrm{~m}$, depending on the species, growth habit and environment. Some species have distinct markings on their leaves. Terminal and auxiliary inflorescences occur. The small seeds of the leafy amaranths are usually very shiny and dark brown to black, contrary to the grain types, which usually have seeds that are cream coloured. Different species of amaranth are utilized all over South Africa, except in the arid south western areas (Schippers, 2000; Van Wyk and Gericke, 2000; Vorster et al., 2002; Hart and Vorster, 2006).

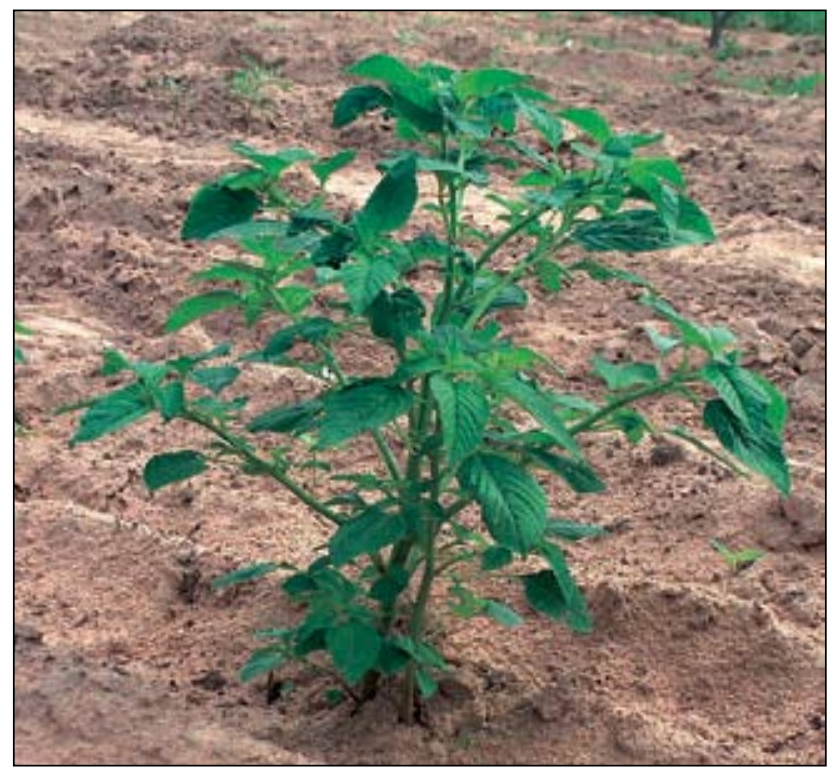

Figure 1

Young amaranth plant (Amaranthus cruentus)

Amaranth is a C4 plant that grows optimally under warm conditions (day temperatures above $25^{\circ} \mathrm{C}$ and night temperatures not lower than $15^{\circ} \mathrm{C}$, bright light and adequate availability of plant nutrients (Van den Heever and Coertze, 1996a; Maboko, 1999; Schippers, 2000). The various amaranth species are tolerant to adverse climatic conditions (Grubben, 2004; Maundu and Grubben, 2004) and they are quite drought-tolerant, but prolonged dry spells induce flowering and decrease leaf yield (Schippers, 2000; Palada and Chang, 2003). Amaranth is photoperiod sensitive and starts to flower as soon as the day length 
shortens. Under cultivated conditions amaranth produces fresh leaf yields of up to $40 \mathrm{t} \mathrm{ha}^{-1}$ (Van den Heever and Coertze, 1996a; Maboko, 1999; Schippers, 2000; Mhlonthlo et al., 2006).

Amaranthus thunbergii (L), A. greazicans, (L), A. spinosus (L), A. deflexus (L), A. hypochondriacus (L), A. viridus (L) and $A$. hybridus (L) are among the most widely used amaranth species in South Africa (Fox and Norwood Young, 1982; Schippers, 2000; Van Wyk and Gericke, 2000; Vorster et al., 2002; Hart and Vorster, 2006). The young leaves, growth points and whole seedlings of amaranth are harvested and cooked for use as a vegetable. Amaranth has also got other uses. In the Tzaneen area the leaves and stems of $A$. spinosis are dried and ground for use as snuff (Hart and Vorster, 2006). In areas where in the past access to salt was limited, such as in parts of the Limpopo Province, the whole dried plants of different amaranth species were burnt to produce ash, which was dissolved in water and the precipitate of the filtrate of the ash was used as salt (Fox and Norwood Young, 1982).

Amaranth is rarely cultivated in South Africa because as with many other African leafy vegetables people believe the plants will grow naturally. In the Bushbuckridge area of the Limpopo and Mpumalanga Provinces women do harvest and store seed of amaranth, which they broadcast in their fields when they observe a decline in the population. Women also practise selective weeding to replenish natural seed reserves (Vorster et al., 2002; Hart and Vorster, 2006). Selective weeding refers to the control of weeds with due regard to the weed species concerned. When practising selective weeding, African leafy vegetable species, such as amaranth, are treated as crops and allowed to grow without being disturbed, whilst other weed species, which are not used as food, are controlled. When selective weeding is used with the intention of raising the natural population of a particular weedy leafy vegetable species, the plants are left in the field to complete their full life cycle, including the release of seed. Of all the weeds that feature as leafy vegetables in South Africa, amaranth is part of the group of species that have potential to be developed as crops.

\section{Spider flower (Cleome gynandra L.)}

Cleome is known as oorpeultjie, palmbossie, vingerblaartee in Afrikaans; spider flower or plant, cats whiskers and African cabbage in English; lude, ulude, ulube in isiNdebele; amazonde in isiZulu; lerotho in Sepedi and Sesotho; murudi in Tshivenda; rirhudzu, bangala in Xitsonga; and nyere, tsuna in Shona which is spoken in Zimbabwe (Fox and Norwood Young, 1982; Bromilow, 1995; Van Wyk and Gericke, 2000, Vorster et al., 2002).

Cleome belongs to the Capparaceae family and is an herbaceous, erect, mainly branched plant (Fig. 2). The height of the plant varies between $0.5 \mathrm{~m}$ and $1.5 \mathrm{~m}$, depending on the environment. Leaves are compound and palmate with three to seven leaflets. Stems and leaves are covered with glandular hair. Pigmentation on the stems varies from green to pink and purple. The terminal inflorescences have very distinct small white flowers, but pink and lilac coloured flowers also occur. The fruit consists of small siliques (Van Wyk and Gericke, 2000).

Among the different Cleome species that occur, Cleome gynandra is the most widely used as a leafy vegetable but C. monophylla and C. hirta, which are close relatives, are also used occasionally. C. hirta has bright pink, purple and white flowers and is a popular ornamental plant in South African gardens (Fox and Norwood Young, 1982; Van den Heever and Coertze, 1996b; Chweya and Mnzava, 1997; Schippers, 2000; Van Wyk and Gericke, 2000; Vorster et al., 2002; Hart and Vorster, 2006).

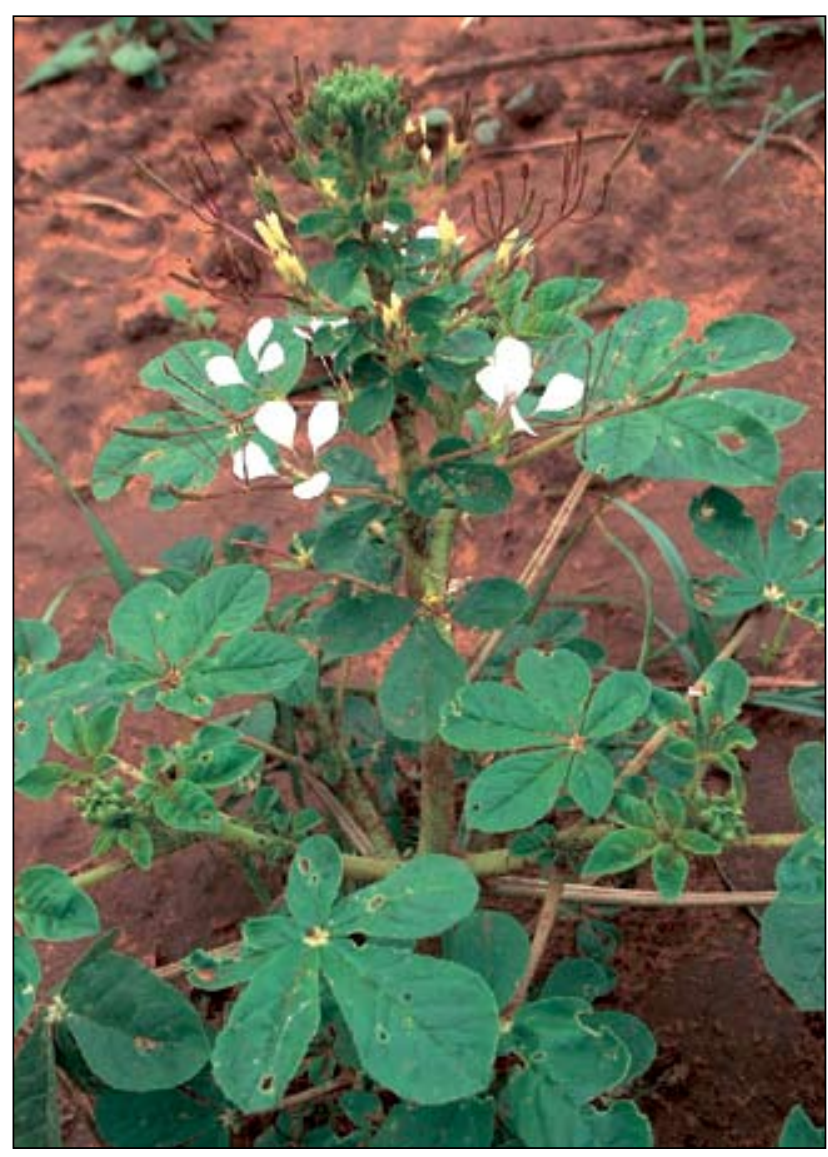

Figure 2

Spider flower (Cleome gynandra)

Cleome grows best during summer and is sensitive to cold. It does not grow well when the temperature drops below $15^{\circ} \mathrm{C}$. Cleome prefers well drained medium-textured soils and does not grow well in poorly drained or heavy clay soils. It requires full exposure to sunlight and performs poorly when shaded. Cleome grows best when adequately supplied with water. It does tolerate a degree of water stress, but prolonged water stress hastens flowering and senescence. Application of fertilisers containing appreciable amounts of nitrogen delays flowering and increases the number and size of leaves. Spider flower is harvested by uprooting and ratoon harvesting (Van den Heever and Coertze, 1996b; Chweya and Mnzava, 1997; Schippers, 2000; Schippers et al., 2002b; AVRDC, 2003; Mnzava and Chigumira Ngwerume, 2004).

In the hot northern parts of South Africa where Cleome grows naturally it is generally preferred to amaranth. The plant parts used include the leaves and the growth tips. People in the south find Cleome too bitter but bitterness can be reduced by changing the cooking water, or by cooking it in milk. When preparing Cleome as a vegetable, amaranth leaves are often added to increase bulk (Fox and Norwood Young, 1982; Chweya and Mnzava, 1997; Van den Heever and Coertze, 1996b; Van Wyk and Gericke, 2000; Vorster et al., 2002; Hart and Vorster, 2006).

Cleome is not formally cultivated in South Africa, but as with amaranth women occasionally raise the natural weedy population by broadcasting seed or by practising selective weeding (Vorster et al., 2002; Hart and Vorster, 2006). Cleome is also among the group of African leafy vegetables that has good potential for development as a crop, particularly in the north of South Africa (Fox and Norwood Young, 1982). 


\section{Chinese cabbage (Brassica rapa L. subsp. chinensis)}

Chinese cabbage is known as Chinese cabbage, rape or Chinese mustard cabbage in English, Sjinese kool in Afrikaans and mutshaina in Tshivenda and other local African languages.

Chinese cabbage is a member of the Cruciferae family. Brassica campestris, the progenitor form of Chinese cabbage, is believed to have evolved in the Mediterranean area. It was introduced to China more than 2000 years ago, where farmers developed two main types, namely heading Chinese cabbage (Brassica rapa L. subsp. pekinensis) and non-heading types (Brassica rapa L. subsp. chinensis). Heading Chinese cabbage forms a compact to elongated head with green crinkled leaves and white midribs whilst in non-heading Chinese cabbage, dark green leaves supported by light green to white petioles form a rosette (Fig. 3) (Opeňa, Kuo and Yoon, 1988; Hill, 1990; Rubatzky and Yamaguchi, 1997). Chinese cabbage is an annual, flowering vegetable which takes 6 to 11 weeks from sowing to the end of the vegetative stage, when the plants reach a height of $15 \mathrm{~cm}$ to $30 \mathrm{~cm}$ (Manrique, 1993; Rubatzky and Yamaguchi, 1997; Hong$\mathrm{Fu}, 1988)$. It has a stout taproot, which is sometimes partly swollen. The inflorescence is a terminal umbel-like raceme which can be up to $60 \mathrm{~cm}$ long (Toxopeus and Baas, 2004).

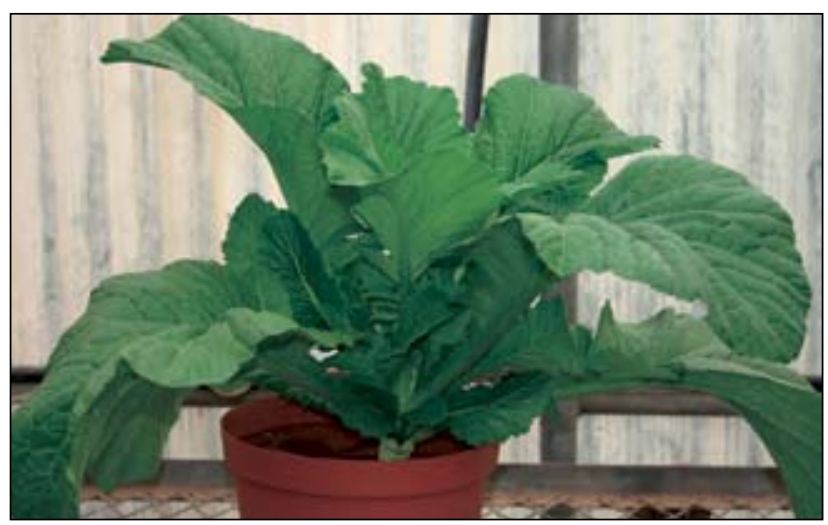

Figure 3

The dabadaba landrace of non-heading Chinese cabbage (Brassica rapa subsp. chinensis)

Chinese cabbage is a cool season crop which requires adequate availability of soil water and plant nutrients for optimum growth (Tshikalange and Van Averbeke, 2006b) and does not tolerate poorly drained conditions. The fresh leaf yield of Chinese cabbage typically ranges between $5 \mathrm{t}^{\mathrm{h}} \mathrm{ha}^{-1}$ and $30 \mathrm{t} \cdot \mathrm{ha}^{-1}$ (Tindall, 1983), with date of planting being an important yield factor (Juma et al., 2005).

Among black people in South Africa, the non-heading Brassica rapa supsp. chinensis is by far the most popular type of Chinese cabbage (Tshikalange and Van Averbeke, 2006a). Closely related Ethiopian Kale or Ethiopian Mustard (Brassica carinata and B. juncea) are popular in central and east Africa. Both of these species are indigenous to Africa. Brassica napus or rape kale is very popular in the Limpopo and Mpumalanga Provinces of South Africa and Zimbabwe, where it is known as murhodisia (Schippers, 2000; Toxopeus and Mvere, 2004). A common characteristic of all Brassica species is the presence of glucosinolate compounds, which are converted by the enzyme myrosinase to give bitter-tasting and gitrogenic substances, such as isothiocyanates, nitriles and goitrin (Peirce, 1987; Rubatzky and Yamaguchi, 1997). These compounds contribute to flavour and odour, but they also inhibit thyroxin production and cause thyroid enlargement, known as goitre, when consumed in large quantities (Schippers, 2000).

Vhembe District in the north of Limpopo Province is the centre of origin of the cultivation of non-heading Chinese cabbage in South Africa, where an informal seed multiplication and distribution system is being maintained by selected producers (Tshikalanga and Van Averbeke, 2006a). Despite the absence of any extension efforts to promote the crop, its cultivation by African smallholders has been rapidly spreading from Vhembe District to many parts of the Limpopo, Mpumalanga and Gauteng Provinces.

\section{Nightshade (S. nigrum complex)}

Nightshade (English) is known as nastergal, galbessie and nagskade in Afrikaans; ixabaxaba in isiNdebele; umsobo, sheshoabohloko and umsobo-sobo in isiXhosa; umsobo, isihlalakuhe, udoye, umagqa, umgwaba, umsobo-sobo (fruit) and umqunbane in isiZulu; lethotho in isiPedi; seshoa-bohloko, sehloabohloko and momoli in Sesotho; msobo and umsobo in siSwati; muxe in Tshivenda; kophe in Xitsonga; and musaka in Shona (Fox and Norwood Young, 1982; Bromilow, 1995; Van Wyk and Gericke, 2000, Vorster et al., 2002).

Nightshades ( $S$. nigrum complex) are erect, branched annual or biannual herbaceous plants that can reach a height of $75 \mathrm{~cm}$ (Fig. 4). The leaves are alternate and bright green in colour but purple pigmentation may be present. The small flowers are about $4 \mathrm{~mm}$ to $10 \mathrm{~mm}$ long with white petals and conspicuous yellow anthers that are arranged in a drooping umbel-like inflorescence (Fig. 5). Nightshade is also known for its small, shiny, black to purple-black fruit used to make jam (Fox and Norwood Young, 1982).

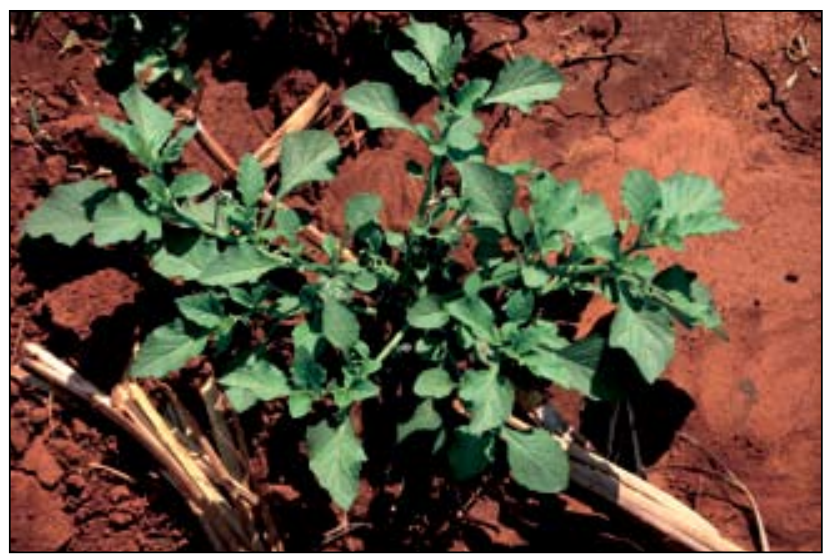

Figure 4

Young nightshade plant (Solanum retroflexum)

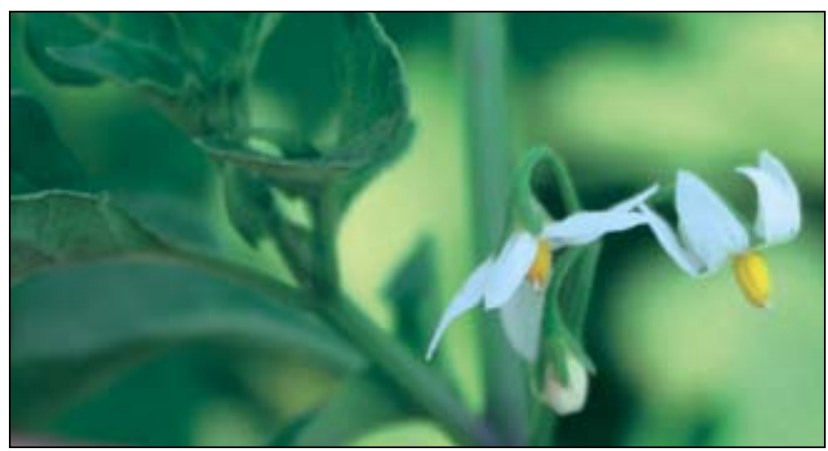

Figure 5

The backwards reflection of the petals is characteristic of Solanum retroflexum 
In nature $S$. nigrum species are mainly found in fairly humid environments with at least $500 \mathrm{~mm}$ of rain per annum (Edmonds and Chweya, 1997). They prefer fertile soils with high nitrogen and phosphorus contents (Van Averbeke and Juma, 2006b). The optimal temperature for growth ranges between $20^{\circ} \mathrm{C}$ and $30^{\circ} \mathrm{C}$, but most species will tolerate a temperature range of $15^{\circ} \mathrm{C}$ to $35^{\circ} \mathrm{C}$. When grown during winter, maximum growth and biomass production are obtained when the plants are exposed to full sunlight, whilst during summer shading up to $60 \%$ can be beneficial (Edmonds and Chweya, 1997). The yield potential of $S$. nigrum species depends on several factors, including type of species, length of the growing season, number of harvests and agro-ecological conditions, but under favourable conditions cumulative leaf yields of $20 \mathrm{t}^{\mathrm{th}} \mathrm{h}^{-1}$ can be achieved. Plant spacing, nutrient and water supply and plant protection are the important crop management practices that determine to what extent the yield potential will be realised (Edmonds and Chweya, 1997).

The nightshade complex contains many species and its taxonomy is complicated. In South Africa $S$. americanum S. nigrum and S. retroflexum are the most commonly used species (Schippers, 2000; Manoko and Van den Weerden, 2004). When used as a leafy vegetable, the leaves and tender shoots of nightshade are harvested and cooked (Van Averbeke and Juma 2006a) but Fox and Norwood Young (1982) reported leaves being eaten raw. The ripe fruit is also consumed extensively, either fresh or as a preserve, but the green fruit is poisonous (Fox and Norwood Young, 1982).

In South Africa nightshade is mostly harvested from the wild, except in the Vhembe District where it is being cultivated, with local farmers processing their own seed (Van Averbeke and Juma, 2006a). Elsewhere in Africa S. nigrum species are also commonly propagated by seed, but the use of shoot cuttings as propagules, especially during the rainy season, has also been reported, though plants propagated in this way yield less than those propagated by seed (Edmonds and Chweya, 1997). Poor germination is a commonly encountered problem that has been ascribed to inadequate removal of sugars and germination inhibitors present in the fruit during extraction of the seed (Mwai and Schippers, 2004). Typically, S. nigrum species are ready to harvest when the plants reach a height of approximately $15 \mathrm{~cm}$ (Edmonds and Chweya, 1997), which they attain about four to six weeks after transplanting (Chweya, 1997; Schippers, 2000; Mwai and Schippers, 2004). The preferred harvesting method is to cut the entire shoot, because this encourages re-growth. Regular harvesting of the young shoots and de-budding encourages the production of lateral shoots and extends the harvesting period. Leaves are harvested until the fruit starts to develop and the leaves become narrow, thin and leathery (Manoko and Van den Weerden, 2004; Van Averbeke and Juma, 2006a). Although $S$. retroflexum is being produced commercially by smallholders in Vhembe District, $S$. scabrum probably has better potential for development as a crop because it has more and larger leaves.

\section{Jew's Mallow (Corchorus olitorius and C. tridens)}

Jew's mallow (English) is known as Jute, Wilde jute in Afrikaans; thelele and ligusha in Sepedi, Sesotho and Setswana; delele in Tshivenda; and guxe, ligushe in Xitsonga and Shangaan (Fox and Norwood Young, 1982; Bromilow, 1995; Van Wyk and Gericke, 2000, Vorster et al., 2002).

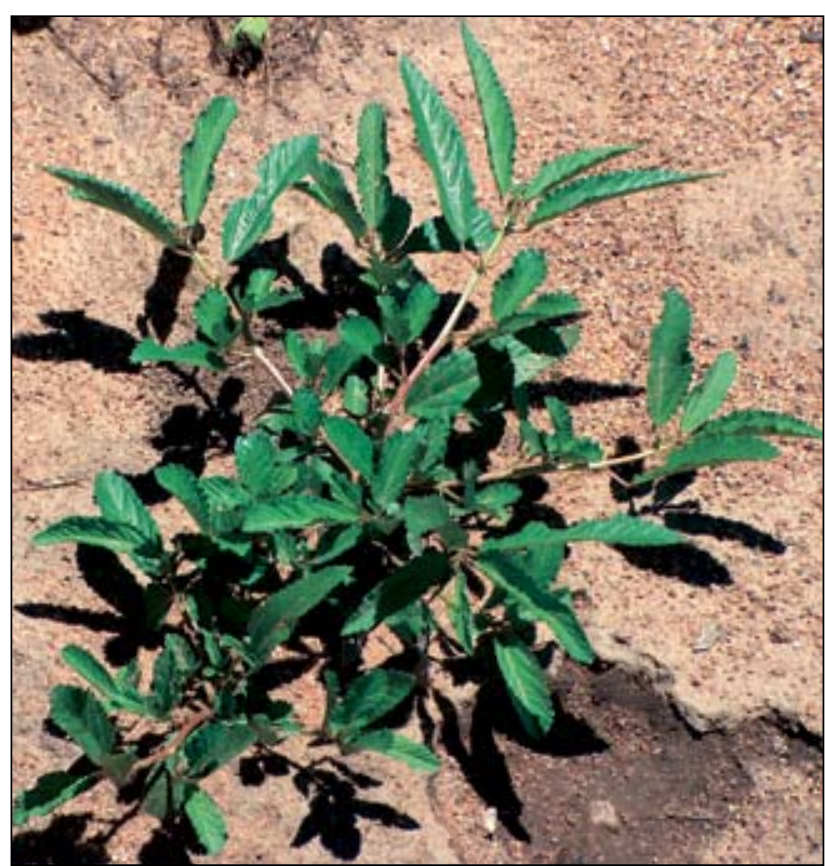

Figure 6

Young Jew's mallow plant (Corchorus olitorius)

Corchorus belongs to the Tiliaceae family and is an erect annual herb that varies from $20 \mathrm{~cm}$ to approximately $1.5 \mathrm{~m}$ in height. The stems are angular with simple oblong to lanceolate leaves that have serrated margins and distinct hair-like teeth at the base (Fig. 6). The bright yellow flowers are usually very small and the fruit is a straight, angular capsule. The capsule of Corchorus tridens ends in three small "horns" (Fox and Norwood Young, 1982). Corchorus seed shows a high degree of dormancy which can be broken by means of hot water treatment (Schippers et al., 2002a).

Corchorus prefers warm, humid conditions and performs well in areas with high rainfall (600 to $2000 \mathrm{~mm}$ ) and high temperature $\left(30^{\circ} \mathrm{C}\right.$ during the day and $25^{\circ} \mathrm{C}$ at night). As a result, it is known only in the northern and eastern regions of South Africa. Growth of Chorcorus slows down considerably when the temperature drops below $15^{\circ} \mathrm{C}$ or when the plants are subjected to a prolonged period of water deficit. Corchorus prefers rich, well-drained, medium-textured soils but will also grow in coarse and fine textured soils. Different chorchorus species are used, namely Corchorus asplenifolius, C. trilocularis, C. tridens and C. olitorius (Schippers et al., 2002a; Van Wyk and Gericke, 2000). Cooked Corchorus has a mucilaginous texture, similar to okra (Abelmoschus esculentus). This sliminess is highly appreciated by people in the north of South Africa but not in the south. When preparing coarse-textured leaves, such as those of cowpeas, inclusion of Corchorus makes it easier for older people to swallow the vegetables. To reduce the sliminess bicarbonate of soda or even cow urine are added to the cooking water (Fox and Norwood Young, 1982; Van Wyk and Gericke, 2000; Schippers et al., 2002a).

In South Africa Corchorus is only harvested from the wild, but it has potential for development as a crop, particularly in the north and east of the country. Okra on the other hand is a cultivated crop, albeit on a limited scale. Khuvutlu and Laker (1993) reported the production of okra by African smallholders at the Middle Letaba Irrigation Scheme where the crop was grown for the harvest of leaves supplied to local markets and the fruit for distant urban markets. 


\section{Pumpkin, melons and indigenous cucurbits}

The leaves of the "ordinary" pumpkin (Cucurbita pepeo, C. Moschata and C. maxima) are known as pampoenblare in Afrikaans; ibobola in siNdebele; cetshana in isiXhosa; intanga and umliba in isiZulu; mphodi, monyaku, motshatsha and mophotse in IsiPedi; mekopu and maphutse/lephotse in Sesotho and Setswana, phuri and thanga in Tshivenda; and tinwembe in Xitsonga. The leaves of the bitter melon (Citrillus lanatus) are known as bitterwaatlemoenblare; karkoerblare and maketaanblare in Afrikaans; ibotola in isiNdebele; umxoxozi, ujodo and ityabontyi in isiXhosa; ibece and ikhabe in isiZulu; mogapu, habu, lethikithi, mathikithi, lerotse, matyathya, motshatsha and mochacha in IsiPedi; lehapu, makakabane, tjoto and thoomo in Sesotho; makataan, kgengwe, lekatane and makopuntji in Setswana; brani and gwadi Tshivenda, bawora, majoda and manwiwi in Shona; and t'samma in Khoisan (Fox and Norwood Young, 1982; Bromilow, 1995; Van Wyk and Gericke, 2000, Vorster et al., 2002).

Members of the Cucurbitaceae all almost all vine like, annual, herbaceous plants. The leaves and stems of some species are covered in sharp, stiff translucent hairs that can irritate the human skin. The leaves vary considerably in shape and size from almost entire leaves to deeply lobed leaves that vary from dark to light green in colour. Flowers are monoecious, yellow or white and vary in size. Fruit also vary in size and colour (Fox and Norwood Young, 1982). Some cucurbits also grow in the wild from where they are harvested. The most popular cucurbit species are the bitter water melon (Citrullus lanatus (Thunb.), the melon (Cucumis melo), the bottle gourd or calabash (Lagenaria siceraria) and the pumpkins and squashes (Cucurbita pepo, $C$. maxima and C. moschata) (Bosch, 1998; Coertze, 1996; Schippers, 2000). The leaves of nkaka, balsam pear or laloentjie (Momordica balsamina), a local climber, are a popular vegetable in the eastern parts of South Africa (Fox and Norwood Young, 1982; Van Wyk and Gericke, 2000; Vorster et al., 2002; Hart and Vorster, 2006).

Cucurbita maxima and C. pepo are drought tolerant and require relatively little water, but they respond positively to irrigation when conditions are very dry (Chigumira Ngwerume and Grubben, 2004; Messiaen and Fagbayide, 2004). C moschata is the most heat tolerant type of pumpkin and it is also fairly drought tolerant (Grubben and Chigumira Ngwerume, 2004). Cucurbits respond well to fertilisers, particularly farm manure.

Members of the Cucurbitaceaea (pumpkin and relatives) family are very popular leafy vegetables in South Africa and one of the few African leafy vegetables that are cultivated (Fig. 7). When harvested as a leafy vegetable, the leaves, flowers and young fruit are picked and cooked. The roasted seed is also a very popular snack (Fox and Norwood Young, 1982; Van Wyk and Gericke, 2000; Vorster et al., 2002, Hart and Vorster, 2006). The fruit of the bitter melon and other indigenous cucurbits are also well known sources of water in desert areas (Fox and Norwood Young, 1982; Van Wyk and Gericke, 2000).

In South Africa, pumpkins and melons are often grown as a minor crop with maize covering the soil surface which helps to control weeds (Fig. 8) (Silwana, 2000; Schippers, 2000; Vorster et al., 2002). Cucurbits are directly sown in spring after the period with frost has ended. Runner crops occupy a lot of space and spacing of the plants is usually wide, ranging from $0.75 \mathrm{~m} \mathrm{x}$ $1 \mathrm{~m}$ to $2 \mathrm{~m}$ x $2 \mathrm{~m}$ (Schippers, 2000).

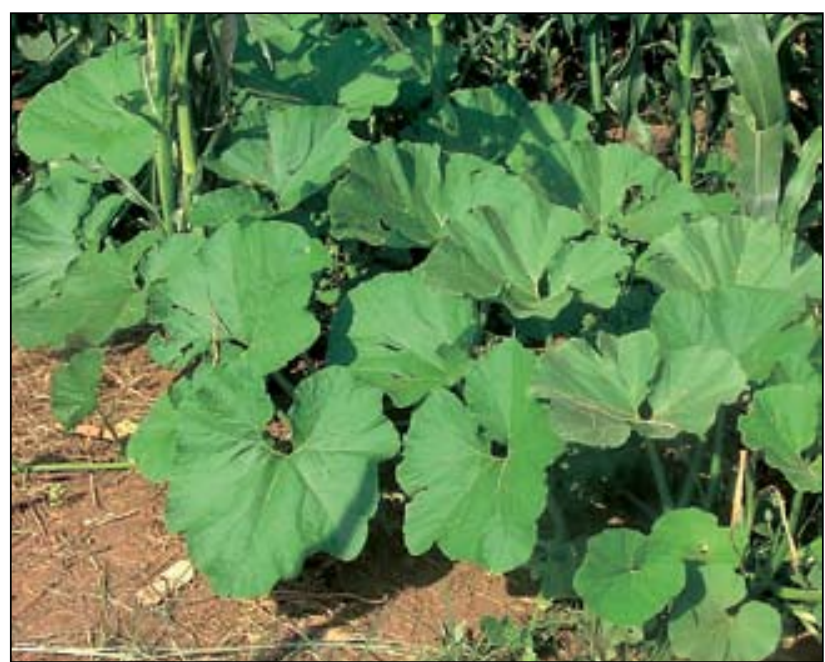

Figure 7

Using the leaves, flowers and young fruit of pumpkins to prepare leafy vegetable dishes is very popular in South Africa

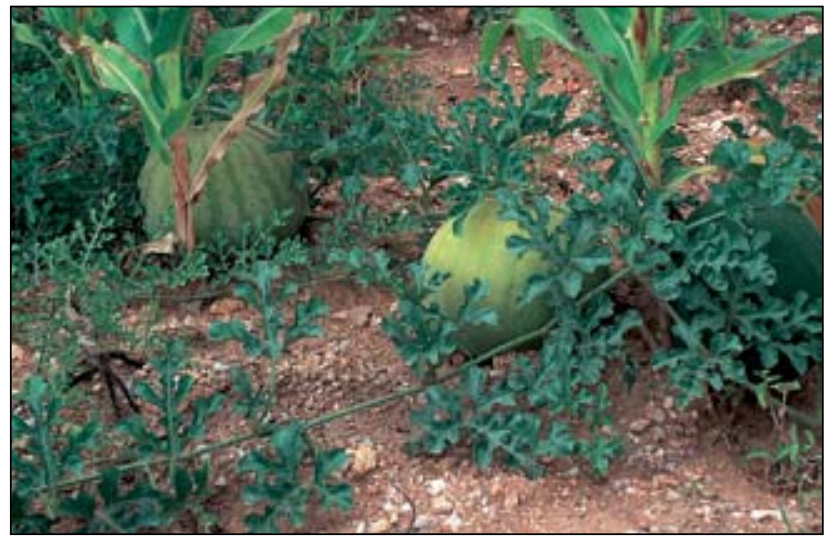

Figure 8

In dry parts of South Africa, African smallholders often grow bitter water melon (Citrillus lanatus) as a minor crop in maize fields

\section{Cowpeas (Vigna inguiculata L.)}

Cowpeas are known as akkerboontjie, koertjie in Afrikaans; dinawa in isiNdebele; iimbotyi in isiXhosa; imbumba, indumba, isihlumanya in isiZulu; monawa in Sepedi; monawa, dinawa, nawa in Sesotho; dinawa, nawa-ea-setswana in Setswana; munawa (plant), nawa (beans) in Tshivenda; dinaba, munaoa, tinyawa in Xitsonga; and murowi we nyemba in Shona (Fox and Norwood Young, 1982; Bromilow, 1995; Van Wyk and Gericke, 2000, Vorster et al., 2002).

Cowpeas are a leaf and pulse crop that belongs to the Leguminosae family. They are annual or perennial herbaceous plants with tri-foliate leaves (Fig. 9 - see next page). Different varieties exist, varying from prostate indeterminate types to erect, determinate, low-branching types. The varieties mainly used as a leafy vegetable are the spreading, prostrate types. The seed is reniform to oblong and varies in colour from white to dark red and black. The seed is often mottled or shows a black "eye" at the hilum. Cowpeas are indigenous to Africa and have been cultivated for a long time on the continent (Fox and Norwood Young, 1982; Schippers, 2000; Vorster et al., 2002; Hart and Vorster, 2006). Various subspecies of cowpeas are found in the wild in the eastern parts of the KwaZulu-Natal, Mphumalanga 


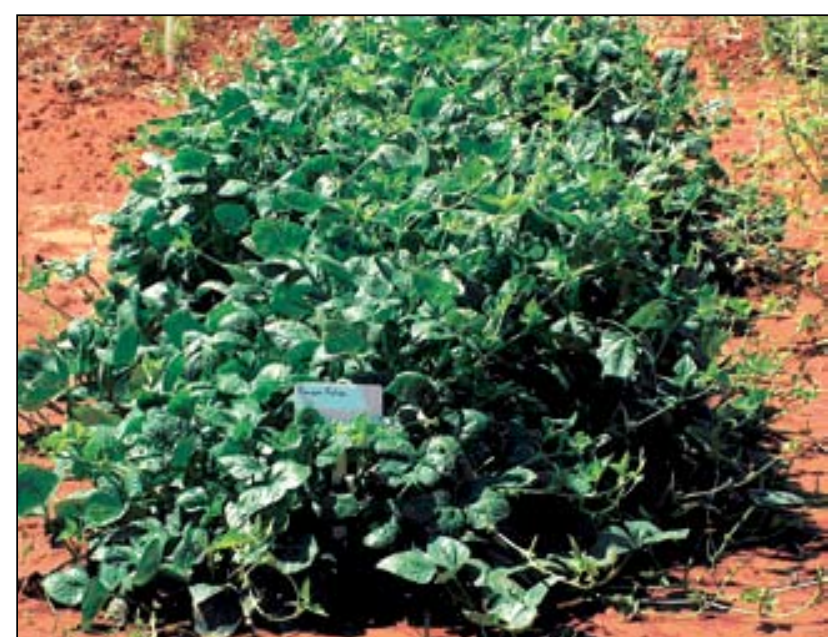

Figure 9

Cowpeas (Vigna inguiculata)

and Limpopo Provinces. These subspecies include Vigna unguiculata subspp. dekindtiana var. dekindtiana, V. unguiculata subspp. dekindtiana var. huillensis, $V$. unguiculata subspp. rotracta, $V$. unguiculata subspp stenophylla, $V$. unguiculata subspp. tenuis var. ovata, V. unguiculata subspp. unguiculata, with Vigna unguicalata subsp. unguiculata the most commonly found (Vorster et al., 2002).

Cowpeas are a heat-loving, drought tolerant crop that has lower soil fertility requirements than many other crops. Cowpeas derive an important amount of their nitrogen requirements from the atmosphere (Schippers, 2000). They are resistant to major bacterial, fungal and viral diseases and to root knot nematodes and important parasitic weeds (Singh, 2006). All of these attributes make the crop well suited for inclusion in South African smallholder systems.

Cowpeas are primarily grown for grain but young leaves and growth points are used as a leafy vegetable. They are often grown in a mixed cropping system with taller crops, such as maize, and are especially important in the dry regions. Harvesting of the leaves commences as soon as plants are well established (Schippers, 2000; Vorster et al., 2002; Hart and Vorster, 2006). After flower initiation when the leaves become very fibrous they are no longer harvested (Schippers, 2000; Vorster et al., 2002; Hart and Vorster, 2006).

\section{Conclusions}

The well-known Pedi proverb, 'Meat is a visitor but morogo is a daily food', captures the important role leafy vegetables have played and continue to play in the food systems of African people in South Africa. Urbanisation and the influence of urban life style on the rural African population resulting from urban-rural linkages are altering the species composition of morogo in favour of western vegetable species, particularly Swiss chard. In the rural areas, indigenous and indigenised leafy vegetables, growing in the wild, as weeds in cropped fields or cultivated are still used extensively by contemporary households in this country and the potential to develop selected species into commodities has been recognised. At community and household level, knowledge associated with these vegetables is essentially passed on from one generation to the next and in certain parts there is the risk that this knowledge can be lost. Considering their potential nutritional value, indigenous and indigenised leafy vegetables could contribute in a major way to the food security and balanced diets of rural households and possibly also urban households. Questions about the bioavailability of the nutrients they contain have been asked and these need to be answered urgently. Further research on the different aspects of African leafy vegetables species, including their ecology, use, cultivation and nutritional contribution is therefore warranted.

\section{Acknowledgement}

This article is based on work done in terms of a research project that is being supported financially by the South African Water Research Commission (WRC Project No. K5/1579//4) but the authors accept full liability for any opinions, findings, conclusions or recommendations contained in this article.

\section{References}

AVRDC (2003) Spider Plant. AVRDC International Cooperators' Fact sheet. AVRDC-The World Vegetable Center, Shanhua, Taiwan. 2 pp.

BHAT RB and RUBULUZA T (2002) The bio-diversity of traditional vegetables of the Transkei region in the Eastern Cape of South Africa. S. Afr. J. Bot. 68 (1) 94-99.

BOSCH SE (1998) Rankgewasse C.1 Pampoen en Skorsiecultivars. Agricultural Research Council Leaflet. ARC-VOPI, Pretoria, South Africa. 4 pp.

BROMILOW C (1995) Problem Plants of South Africa. Briza Publications, Pretoria, South Africa. $315 \mathrm{pp}$.

BUNDY C (1988) The Rise and Fall of the South African Peasantry ( $2^{\text {nd }}$ edn.) David Philip, Cape Town, South Africa. 276 pp.

CHIGUMIRA NGWERUME F and GRUBBEN GJH (2004) Cucurbita maxima Duchesne In: Grubben GJH and Denton OA (eds.) PROTA 2: Vegetables/Légumes [CD-Rom]. PROTA, Wageningen, The Netherlands. 263-267.

CHWEYA JA (1997) Genetic enhancement of indigenous vegetable in Kenya. In: Guarino L (ed.) Traditional African Vegetables. International Plant Genetic Resources Institute (IPGRI), Rome, Italy. 86-95.

CHWEYA JA and MNZAVA NA (1997) Promoting the Conservation and Use of Underutilized and Neglected Crops. 11. Cat's Whiskers. IPGRI, Rome, Italy. 53 pp.

COERTZE AF (1996) Rankgewasse D2: Waatlemoene. Agricultural Research Council Leaflet. ARC-VOPI, Pretoria, South Africa. 4 pp.

DEPARTMENT OF AGRICULTURE (2004) Strategic Plan for the Department of Agriculture 2004: Consolidating the Partnership for Poverty Eradication, Accelerated Growth and Wealth Creation. Directorate Agricultural Information Services, Pretoria. 160 pp.

EDMONDS JM and CHWEYA JA (1997) Black nightshades: Solanum nigrum $L$. and related species: promoting the conservation and use of underutilized and neglected crops. IPGRI, Rome. [Online]. Available from: http://www.bioversityinternational.org/publications/pufile.asp? pub=337 (Accessed on 22/03/07).

DOVIE DBK, SHACKLETON CM and WITKOWSKI ETF (2002) Direct-use values of woodland resources consumed and traded in a South African village. Int. J. Sustain. Dev. World Ecol. 9 269-283.

FOX FW and NORWOOD YOUNG ME (1982) Food from the Veld: Edible Wild Plants of Southern Africa. Delta Books, Johannesburg, South Africa. 399 pp.

GRABANDT K (1985) Weeds of Crops and Garden in South Africa. Ciba-Geigy (Pty) Ltd, Johannesburg. 134 pp.

GRUBBEN GJH (2004) Amaranthus cruentus L. In: Grubben GJH and Denton OA (eds.) PROTA 2: Vegetables/Légumes [CD-Rom]. PROTA, Wageningen, The Netherlands. 71-72.

GRUBBEN GJH and CHIGUMIRA NGWERUME F (2004) Cucurbita moschata Duchesne. In: Grubben GJH and Denton OA (eds.) PROTA 2: Vegetables/Légumes [CD-Rom]. PROTA, Wageningen, The Netherlands. 267-273.

HART TGB and VORSTER HJ (2006) Indigenous Knowledge on the South African Landscape - Potentials for Agricultural Development. Urban, Rural and Economic Development Programme. Occasional paper No 1. HSRC Press, Cape Town, South Africa. 52 pp. 
HILL DE (1990) Chinese Cabbage and Pak Choi Trials 1988-1989. Bulletin 879. The Connecticut Agricultural Experiment Station, New Haven, USA. 12 pp.

HONG-FU Y (1988) The effect of nitrogen fertilizer application on the yield of Chinese cabbage. Available from: http://www.arc-avrdc. org/pdf files/Yanghongfu(6-N).pdf. (Accessed on 11/03/05).

HUSSELMAN M and SIZANE N (2006) Imifino. A Guide to the Use of Wild Leafy Vegetables in the Eastern Cape. ISER Monograph Two. Institute for Social and Economic Research, Rhodes University, Grahamstown, South Africa.

JANSEN VAN RENSBURG WS and VORSTER HJ (2005) The utilization of traditional leafy vegetables. $6^{\text {th }}$ International Food Data Conference, 14-16 September 2005, University of Pretoria, Pretoria, South Africa. Unpublished. Available from ARC-VOPI, Pretoria, South Africa. 12 pp.

JANSEN VAN RENSBURG WS, VENTER SL, NETSHILUVHI TR, VAN DEN HEEVER E, VORSTER HJ and DE RONDE JA (2004) The role of indigenous leafy vegetables in combating hunger and malnutrition. SA J. Bot. 70 (1) 52-59.

JUMA KA, NETSHITHUTHUNI NC, TSHIKALANGE TE and VAN AVERBEKE W (2005) Improving production of indigenous vegetables. In: Van Averbeke W (Comp.) Best Management Practices for Small-Scale Subsistence Farming on Selected Irrigation Schemes and Surrounding Areas through Participatory Adaptive Research: 2004-05 Annual Report, Centre for Organic and Smallholder Agriculture, Tshwane University of Technology, Pretoria, South Africa. 124-172.

KHUVUTLU I and LAKER MC (1993) Identifying constraints and opportunities for farmers at Middle Letaba Irrigation Project using a low cost appraisal approach.. FSRE-E South. Afr. Newslett. 5 6-16.

KIRSTEN CM (1977) The compliment of the cereal diet of Transkei people in the Mount Ayliff District. J. Diet. Sci. Home Econ. 5 $19-22$

MABOKO SM (1999) Vegetable amaranth improvement for South Africa [Online]. Available from: http://www.newcrops.uq.edu.au/ newslett/ncn11169.htm. [Accessed: 19/03/2007].

MAGASELA BB, WATSON HK, MHANGO BJ and BOB U (2001) Direct-Use Values of Non-Timber Forest Products from the Rural Area of Hlabisa, KwaZulu-Natal, RSA. University of Durban-Westville, Durban. 43 pp.

MANOKO ML and VAN DER WEERDEN GM (2004) Solanum americanum Mill. In: Grubben GJH and Denton OA (Eds.) PROTA 2: Vegetables/Légumes [CD-Rom]. PROTA, Wageningen, The Netherlands. 477-480.

MANRIQUE LA (1993) Greenhouse crops: A review. J. Plant Nutr. 16 (22) 2411-2477.

MAUNDU PM and GRUBBEN GJH (2004) Amaranthus graecizans L. In: GRUBBEN GJH and DENTON OA (Eds.) PROTA 2: Vegetables/Légumes [CD-Rom]. PROTA, Wageningen, The Netherlands. 76-78.

MESSIAEN CM and FAGBAYIDE JA (2004) Cucurbita pepo L. In: Grubben GJH and Denton OA (Eds.) PROTA 2: Vegetables/Légumes [CD-Rom]. PROTA, Wageningen, The Netherlands. 272-277.

MHLONTHLO S, MUCHAONYERWA P, MNKENI PNS and MAPHAHA MF (2006) Effects of sheep kraal manure in dry matter yield and leaf nutrient composition of Amaranthus in the central region of the Eastern Cape Province, South Africa. In: Proc. Int. Symp. on the Nutrition and Water Use of Indigenous Crops for Improved Livelihoods. 19-20 September 2006, University of Pretoria, Pretoria. [CD ROM]. The Centre for Nutrition, University of Pretoria, Pretoria. No page numbers.

MNZAVA NA and CHIGUMIRA NGWERUME F (2004) Cleome gynandra L. In: Grubben GJH and Denton OA (Eds.) PROTA 2: Vegetables/Légumes [CD-Rom]. PROTA, Wageningen, The Netherlands. 191-195.

MODI M, MODI A and HENDRIKS S (2006) Potential role for wild vegetables in household food security: a preliminary case study in KwaZulu-Natal, South Africa. Afr. J. Food, Agric. Nutr. Dev. 6 (1) 1-13.

MWAI GN and SCHIPPERS RR (2004) Solanum florulentum Bitter: Plant resources of tropical Africa [Online]. Available from: (Accessed on 02/07/2004).
OPEŇA RT, KUO CG and YOON JY (1988) Breeding and Seed Production of Chinese Cabbage in the Tropics and Subtropics. Technical Bulletin No 17. Shanshua, Taiwan: Asian Vegetable Research and Development Center (AVRDC). 92 pp.

PALADA MC and CHANG LC (2003) Suggested Cultural Practices for Vegetable Amaranth. International Cooperates Guide, AVRDC pub \#03-552. AVRDC-The World Vegetable Center, Shanhua, Taiwan. $4 \mathrm{pp}$.

PARSONS N (1993) A New History of Southern Africa $\left(2^{\text {nd }}\right.$ edn.) MacMillan, London. 349 pp.

PEIRCE LC (1987) Vegetables: Characteristics, Production and Marketing. John Wiley \& Sons, New York, USA. 448pp.

PEIRES JB (1981) The House of Phalo: A History of the Xhosa People in the Days of their Independence. Ravan Press, Johannesburg. 314 pp.

PHILLIPS-HOWARD KD (1999) The indigenization of exotic inputs by small-scale farmers on the Jos Plateau, Nigeria. In: Prain G, Fujisaka S and Warren MD (eds.) Biological and Cultural Diversity: The Role of Indigenous Agricultural Experimentation in Development. Intermediate Technology Publications, London, UK. 80-91.

ROSE EF and GUILLARMOD AJ (1974) Plants gathered as foodstuffs by the Transkeian peoples. Suid-Afrikaanse Mediese Tydskrif $\mathbf{8 6}$ 1688-1690.

RUBAIHAYO EB (1997) Conservation and use of traditional vegetables in Uganda. In: Guarino L (ed.) Traditional African Vegetables. IPGRI, Rome. 104-116.

RUBATZKY VE and YAMAGUCHI M (1997) World Vegetables: Principles and Nutritive Values ( $2^{\text {nd }}$ edn.). Chapman and Hall, New York, USA. 843 pp.

SCHIPPERS RR (2000) African Indigenous Vegetables. An Overview of the Cultivated Species. Natural Resources Institute/ACP-EU Technical Centre for Agricultural and Rural Cooperation, Chatham, UK. 214 pp.

SCHIPPERS RR (2002) African Indigenous Vegetables. An Overview of the Cultivated Species (revised edn.).[CD Rom]. Natural Resources Institute, Chatham, U.K. 245 pp.

SCHIPPERS RR (2006) Traditional vegetables in Africa. In: Proc. Int. Symp. on the Nutritional Value and Water Use of Indigenous Crops for Improved Livelihoods. 19-20 September, University of Pretoria. [CD ROM]. The Centre for Nutrition, University of Pretoria, Pretoria.

SCHIPPERS R, MAUNDU P, IMBUNI M and OBIERO H (2002a) How to Grow and Use Jew's Mallow. Horticultural Development Services, Baarn, The Netherlands. 10 pp.

SCHIPPERS R, MAUNDU P, IMBUNI M and OBIERO H (2002b) How to Grow and Use Spider Plant. Horticultural Development Services, Baarn, The Netherlands. 10 pp.

SHACKLETON CM (2003) The prevalence of use and value of wild edible herbs in South Africa. S. Afr. J. Sci. 99 (January/February) 23-25.

SHACKLETON CM, NETSHILUVHI TR, SHACKLETON SE, GEACH, BS, BALLANNCE A and FAIRBANKS DFK (1999) Direct use values of woodland resources from three rural villages. Report No. ENV-P-I 98210 [Online]. Available from: http://www. odi.org.uk/nrp/62.html(Accessed on19/02/2007).

SHACKLETON SE, SHACKLETON CM and COUSINS B (2000) Revaluing the communal lands of southern Africa: a new understanding of rural livelihoods. ODI Nat. Res. Persp. 62 1-4.

SHACKLETON CM, SHACKLETON SE, NETSHILUVHI TR, GEACH BS, BALLANCE A and FAIRBANKS DFK (2002a) Use patterns and value of savannah resources in three rural villages. Econ. Bot. 56 (2) 130-146.

SHACKLETON CM, SHACKLETON SE, NTSHUDU M and NTZEBEZA JN (2002b) Direct use values of non-timber forest products from three rural villages in the Kat River Valley, Eastern Cape Province. South Africa. J. Trop. For. Prod. 8 (1) 45-65.

SHACKLETON CM, TIMMERMANS HG, NONGWE N, HAMER $\mathrm{N}$ and PALMER R (2007) Direct-use values of non-timber forest products from two areas on the Transkei Wild Coast. Agrekon 46 (1) $135-156$.

SILWANA T (2000) The Performance of Maize/Bean and Maize/Pumpkin Intercrops under Different Planting Combinations and Weeding in Transkei, South Africa'. M.Sc. Dissertation, University of Fort Hare, Alice. 122 pp. 
SINGH BB (2006) Cowpea breeding: Advances, impacts and future. In: Proc. Int. Symp. on the Nutritional Value and Water Use of Indigenous Crops for Improved Livelihoods. 19-20 September 2006, University of Pretoria, Pretoria. [CD ROM]. The Centre for Nutrition, University of Pretoria, Pretoria.

TINDALL HD (1983) Vegetables in the Tropics. Macmillan Press, London, UK. $546 \mathrm{pp}$

TOXOPEUS H and BAAS J (2004) Brassica rapa L. In: Grubben GJH and Denton OA (eds.) PROTA 2: Vegetables/Légumes [CD-Rom]. PROTA, Wageningen, The Netherlands. 146-151.

TOXOPEUS H and MVERE B (2004) Brassica napus L. In: Grubben GJH and Denton OA (eds.) PROTA 2: Vegetables/Légumes [CDRom]. PROTA, Wageningen, The Netherlands. 127-130.

TSHIKALANGE TE and VAN AVERBEKE W (2006a) The cultivation of Brassica rapa L. subsp. chinensis in Vhembe, Limpopo Province, South Africa. In: Proc. Int. Symp. on the Nutritional Value and Water Use of Indigenous Crops for Improved Livelihoods. 19-20 September 2006, University of Pretoria, Pretoria. Volume of papers (not edited) [CD ROM]. The Centre for Nutrition, University of Pretoria, Pretoria. No page numbers.

TSHIKALANGE TE and VAN AVERBEKE W (2006b) Effects of nitrogen, phosphorus and potassium on the production of marketable leaves of Brassica rapa L. subsp. Chinensis in pots. In: Proc. Int. Symp. on the Nutritional Value and Water Use of Indigenous Crops for Improved Livelihoods. 19-20 September 2006, University of Pretoria, Pretoria. [CD ROM]. The Centre for Nutrition, University of Pretoria, Pretoria. No page numbers.

TWINE WC, MOSHE D, NETSHILUVHI TR and SIPHUGU V (2001) Direct-use values of non-timber forest products from the rural area of Mametja, Northern Province, RSA. Wits Rural Facility, Acornhoek. Unpublished.

VAN AVERBEKE W and JUMA KA (2006a) The cultivation of Solanum retroflexum Dun. in Vhembe, Limpopo Province, South Africa. Proc. Int. Symp. on the Nutritional Value and Water Use of Indigenous Crops for Improved Livelihoods. 19-20 September 2006, University of Pretoria, Pretoria. [CD ROM]. The Centre for Nutrition, University of Pretoria, Pretoria. No page numbers.
VAN AVERBEKE W and JUMA KA (2006b) Effects of nitrogen, phosphorus and potassium on above ground biomass of Solanum retroflexum Dun. in pots. Proc. Int. Symp. on the Nutritional Value and Water Use of Indigenous Crops for Improved Livelihoods. 1920 September 2006, University of Pretoria, Pretoria. [CD ROM]. The Centre for Nutrition, University of Pretoria, Pretoria. No page numbers.

VAN DEN HEEVER E and COERTZE AF (1996a) Indigenous Leaf Crops A1 - Amaranthus (marog). Agricultural Research Council Leaflet, ARC-VOPI, Pretoria, South Africa. 2 pp.

VAN DEN HEEVER E and COERTZE AF (1996b) Indigenous Leaf Crops A2-Cleome. Agricultural Research Council Leaflet. ARCVOPI, Pretoria, South Africa. 2 pp.

VAN WYK B and GERICKE N (2000) People's Plants. A Guide to Useful Plants of Southern Africa. Briza Publications, Pretoria, South Africa. 352 pp.

VORSTER HJ, JANSEN VAN RENSBURG WS, VAN ZIJL JJB and VAN DEN HEEVER E (2002) Germplasm Management of African Leafy Vegetables for the Nutritional and Food Security Needs of Vulnerable Groups in South Africa. Progress Report. ARC-VOPI, Pretoria, South Africa. 130 pp.

VORSTER HJ, JANSEN VAN RENSBURG WS, VENTER SL and VAN ZIJL JJB (2005) (Re)-creating awareness of traditional leafy vegetables in communities. Regional workshop on African Leafy Vegetables for Improved Nutrition. Paper presented at Regional Workshop on African Leafy Vegetables for Improved Nutrition, 6-9 December 2005, IPGRI, Nairobi, Kenya (Available from ARCVOPI, Pretoria, South Africa). 6 pp.

WEHMEYER AS and ROSE EF (1983) Important indigenous plants used in the Transkei as food supplements. Bothalia 14 (3/4) 613615

WHITBREAD MW (1986) Preliminary Studies on the Utilization and Adaptation of Indigenous and Introduced Vegetable and Grain Amaranths (Amaranthus spp.) in the Natal and KwaZulu Midlands. M.Sc. (Agric) Dissertation. University of Natal, Pietermaritzburg. $54 \mathrm{pp}$. 